\title{
The Milky Way: Paediatric milk-based dispersible tablets prepared by direct compression - a proof-of-concept study.
}

Samuel Orubu, Nicholas J. Hobson, Abdul W. Basit, Catherine Tuleu.

\section{Authors' affiliation}

Name: Samuel Orubu (corresponding author)

Affiliation:University College London School of Pharmacy, UK

Address: 29 - 39 Brunswick Square, London WC1N 1AX, UK

Tel.: $+44(0) 2077535975$

Fax: $+44(0) 2077535942$

Email: ebiowei.orubu.11@ucl.ac.uk

Name: Nicholas John Hobson

Affiliation:University College London School of Pharmacy, UK Address: $29-39$ Brunswick Square, London WC1N 1AX, U.K

Tel.: +44(0)7402001141

Fax: $+44(0) 2077535942$

Email: nicholas.hobson.12@ucl.ac.uk

Name: Abdul W. Basit

Affiliation: University College London School of Pharmacy, UK Address: $29-39$ Brunswick Square, London WC1N 1AX, U.K

Tel.: +44(0)20 77535865 
Fax: $+44(0) 2077535942$

Email: a.basit@ucl.ac.uk

Name: Catherine Tuleu

Affiliation : University College London School of Pharmacy, UK

Address: 29 - 39 Brunswick Square, London WC1N 1AX, UK

Tel: $+44(0) 2077535857$

Fax: $+44(0) 2077535942$

Email: c.tuleu@ucl.ac.uk

Running title: Directly-compressed milk-based dispersible tablets

Key words: milk-based tablets, direct compression, design-of-experiments

Word count - Total (excluding references, figures and tables): 4214 


\section{Abstract}

Objectives: Dispersible tabletsare proposed by the World Health Organisation as the preferred paediatric formulation. It was hypothesised that tablets made from a powdered milk-base that disperse in water to form suspensions resembling milk might be a useful platform to improve acceptability in children.

Methods: Milk-based dispersible tablets containing various types of powdered milk and infant formulae were formulated. The influence of milk type and content on placebo tablet properties was investigated using a design-of-experiments approach. Responses measured included friability, crushing strength, and disintegration time. Additionally, the influence of compression force on the tablet properties of a model formulation was studied by compaction simulation.

Key findings: Disintegration times increased as milk content increased. Compaction simulation studies showed that compression force influenced disintegration time. These results suggest that the milk content, rather than type, and compression force were the most important determinants of disintegration.

Conclusion: Up to $30 \%$ milk could be incorporated to produce $200 \mathrm{mg} 10 \mathrm{~mm}$ flat-faced placebo tablets by direct compression disintegrating within 3 minutes in $5-10 \mathrm{ml}$ of water, which is a realistic administration volume in children. The platform could accommodate $30 \%$ of a model API (caffeine citrate).

Keywords: Paediatric, milk-based, dispersible tablets, direct compression, design-of-experiments. 


\section{Introduction}

Medicines for children are not always age-appropriate leading to problems with dosing, acceptability and adherence which can affect safety and efficacy of administered medicines $(1,2)$. With young children under 5 years old, the main issues are swallowability of intact conventional solid dosage forms, and palatability $(3,4)$. The World Health Organisation (WHO) proposes flexible solid oral dosage (FSOD) forms as the preferred formulations for children. FSOD forms are medicines made as solids but administrable as other forms; for example dispersible tablets, which are intended to be administered in a small volume of water, or other liquid, to young children (5).

Milk is a highly nutritive product that is known and liked by children. They usually come to know milk through breast milk which has a predominately sweet or umami taste (6-8). Breast milk and liquid milk are composed of about $88 \%$ water, with about $12 \%$ made up of fat, carbohydrates, proteins, minerals and vitamins (9). Commercially, milk obtained from different animalsources is processed by pasteurisation to obtain liquid milk. Removing water from processed liquid milk by spray-drying or other methods produces powdered milk (10).

The Food and Agricultural Organisationand the WHO classify powdered milk into three types differing mainly in their content of milk-fat. These are: (i) whole/full-cream (full-fat) milk with $\geq 26 \%$ weight-in-weight (w/w) milk-fat; (ii) partly-/semi-skimmed milk with milk-fat $>1.5 \%$ but $<26 \% \mathrm{w} / \mathrm{w}$; and (iii) skimmed milk with $<1.5 \% \mathrm{w} / \mathrm{w}$ milk-fat (11). Powdered milk, on reconstitution, yields a dispersion containing $8-12 \% \mathrm{w} / \mathrm{v}$ of milk, simulating the composition of liquid milk (9). While breast milk is recommended for children up to the age of 6 months, for children unable to be exclusively breast-fed, infant formulae are used. From 6 months to 1 year, these formulae can also be used in complementary feeding (12). There are also specialist infant formulae, for example formula with reduced lactose for infants with lactose intolerance (13).

The use of milk in pharmaceutical formulations to improve biopharmaceutical properties is reported in the literature. For instance, full-fat liquid milk has been used to provide gastro-protective effects with non-steroidal anti-inflammatory drugs (NSAIDs), andto improve solubility and bioavailability $(14,15)$. Powdered skimmed milk has also been similarly used to produce a prednisolone formulation with reduced gastric irritation and improved aqueous solubility (16). Liquid semiskimmed milk has been shown to reduce the irritancy, but not bitterness, of ibuprofen (17).Powdered skimmed milk was combined with unpleasant-tasting active pharmaceutical ingredients (APIs), such as nitrazepam, in ratios ranging from 1:1 to 1000 000:1 w/w (skimmed milk: API) to obtain taste masking, however, in association with sweeteners such as sorbitol and mannitol(18). Fewer studies have examined the material properties of powdered milk or infant formula(19-22). The compaction behaviour of the different milk typesand infant formulae, and hence, suitability as potential excipients in dispersible tablets manufactured by direct compression is thus not well understood.

Presently, it was hypothesised that a milk-based dispersible tablet that could be reconstituted in 5$10 \mathrm{ml}$ of water, a typical administration volume, to produce a suspension with similar organoleptic properties as milk would improve acceptability and,subsequently, adherence in young children already familiar with milk. Further, that the ability to produce such tablets by the relatively 
inexpensive direct compression technology would make these tablets accessible in resource-limited settings.

To explore this concept, several powdered milk and infant formulae were assessed for suitability for the DC production of a dispersible tablet using a design-of-experiments (DoE) approach. To be suitable for processing by DC, a powder blend must flow sufficiently well to ensure the production of tablets with uniform weights and undergo densification on the application of a compression force to form a compact. In addition, the tablets produced must meet quality/pharmacopoeial requirements. For a dispersible tablet, these include a disintegration time within 3 minutes in water at room temperature to produce a homogenous dispersion that passes through a $710 \mu \mathrm{m}$ sieve.Blend processability and tablet characteristics are determined by a combination of blend properties (particle size and shape, size distribution, and deformation behaviour), processing (press type, compression force, and tableting speed), and environmental conditions $(23,24)$. DoE is a systematic and efficient approach to experimentation that involves performing experiments in a randomised manner in which several factors are simultaneously varied between certain limits and the response(s) measured. DoE is useful in mapping all possible factor combinations that maximise or minimise a response using response surface modelling in an optimisation objective (25).

The processability and tablet characteristics of a "basic" formulation consisting of powdered milk or infant formula, mannitol as a polyol filler, crospovidone as the superdisintegrant and sodium stearylfumarate as the lubricant was investigated. The influence of milk or formula type on the maximum amount of milk that can be incorporated in a placebo tablet was assessed. Caffeine citrate, used for the treatment of neonatal apnoea (26), was then included as a first model API to determine the feasibility of producing medicated milk-based dispersible tablets by direct compression. This is the first work to evaluate the flowability and compressibility of several different types of powdered milk and infant formula for the DC production of milk-based dispersible tablets as potential delivery platform for young children.

\section{Materials and methods}

\section{Materials}

Powdered milk used were: skimmed milk powder(Marvel ${ }^{\circledR}$, Premier International Foods, UK), and full-cream milk (Nido ${ }^{\circledR}$, Nestle, Switzerland). Powdered infant formulae were: one suitable for use from 0-6 months (Aptamil ${ }^{\circledR} 1$, Danone, UK), and a specialist milk for infants with lactose-intolerance (SMA ${ }^{\circledR}$ Lactose-Free (LF), Wyeth, UK) (Table 1). Mannitol, DC grades (Pearlitol ${ }^{\circledR}$ 300DC, and Pearlitol ${ }^{\circledR}$ 200SD; Roquette, UK); crospovidone (Polyplasdone ${ }^{\circledR} \mathrm{XL}$; ISP, UK); sodium stearylfumarate (Lubripharm ${ }^{\circledR}$; SPI Pharma, USA); caffeine citrate (Fagron, UK).

\section{Methods}

\section{Design-of-experiments}


Experiment design, randomisation, regression analysis, model evaluation and optimisation were performed using a DoE software (MODDE 9.1.1, MKS Umetrics AB, Umea, Sweden). This software allows the user to input factors, and to specify their limits and experiment objective; specify responses and input results after experimentation. Based on factor limits and objective, the software suggests suitable experiments designs or models. After experimentation, the software conducts a statistical analysis of results, and allows for prediction and optimisation depending on experiment objectives.

\section{Experiment objective and design}

Experiment objective was formulation "optimisation" using a determinant optimum (D-optimum) mixture design. The optimum formulation was defined as the one with the maximum amount of milk producing a placebo tablet with a friability $<1 \%$, and a disintegration time within 3 minutes. Experiment design was the D-optimum mixture design, considered suitable as factors were proportions of a mixture which formed an irregular design region best analysed using the $D$ optimum design (30).

\section{Factors and responses}

Four factors (Table 2 ) and ten responses were specified. The responses were: angle-of-repose $(\alpha)$, Carr's Index ( $\mathrm{Cl}$ ), and Hausner ratio (HR) for the powder blends; and disintegration time, fineness of dispersion, tensile strength, uniformity of weight, thickness, diameter, and friability for the tablets. Disintegration time was the only response used in the optimisation studies.

A total of 14 experiments with 11 formulations (N1-N11) and 3 repeats of N11 (N12-N14) were conducted in a randomised order. The formulations were of three distinct types: (i) "high-milk", (ii) "high-mannitol", and (iii) 1:1 milk and mannitol combinations. "High-milk" and "high-mannitol" corresponded to the high level setting for these factors; at the 1:1 combinations (N11-N14) - the design centre point - all factors were at their average levels. The experiments, randomisation or run order, blend properties and mean tablet weights are shown in Table 3.

\section{Modelevaluation and optimisation}

Experimental data was modelled using partial least squares regression analysis. A quadratic model was selected to facilitate the analysis of any interaction between factors. The regression equation, or model, used for data analysis was of the general form:

$$
y=\beta_{0}+\beta_{1} x_{1}+\beta_{2} x_{2}+\beta_{3} x_{3}+\beta_{11} x_{1}^{2}+\beta_{22} x_{2}^{2}+\beta_{33} x_{3}^{2}+\beta_{12} x_{1} x_{2}+\beta_{13} x_{1} x_{3}+\beta_{23} x_{2} x_{3}+\varepsilon
$$

where $y=$ disintegration time, $\beta_{0}$ is the disintegration time at the design centre point, $\beta_{1}-\beta_{3}$ are coefficients, $x_{1}-x_{3}$ are the variable factors, $x_{i}$ and $x_{j}$ are interaction terms, $x_{i}^{2}$ are square terms, and $\varepsilon$ is the residual response variable.

All models were optimised for validity and predictability. Optimisation was performed by the removal of non-significant interaction terms in the regression equation, runs with disintegration times that were outliers (standard deviation > 1.5), or one of the repeats (31). Model validity and predictive power were evaluated using two in-built statistical "diagnostic tools". The first tool was based on analysis of variance (ANOVA). Acceptance criterion with this tool was a model validity $\geq$ 0.25 (corresponding to a $p$ value $\geq 0.05$ ) which indicates no "lack-of-fit" or validity of the model used to analyse the data. The second tool used a set of four parameters to assess model suitability and predictive power (Table 4). Of these four parameters, $Q^{2}$, the goodness-of-prediction, is the most 
important, and its value should be maximised. In a good (very predictive) model, $R^{2}$ and $Q^{2}$ would be as close to 1 as possible. With very good reproducibility (value $>0.9$ ), that is very high agreement among the repeats, model validity in the first tool can be lower than 0.25 . In this case, the second tool becomes very useful (31).

Formulation development and characterisation

\section{Formulation development and characterisation}

Powder particle fractions between 125 and $710 \mu \mathrm{m}$ were used.

\section{Pre-compression characterisation}

$\alpha$

This was determined using the fixed-height cone method with funnel tip maintained at $8 \mathrm{~cm}$ from a stainless steel base $5 \mathrm{~cm}$ in diameter. $\alpha$ was determined $(n=3)$ using the equation:

$$
\tan \alpha=2 h / d
$$

whereh is the height of powder cone $(\mathrm{cm})$, and $d$ is the diameter of the steel base $(\mathrm{cm})$.

$\mathrm{HR}$ and $\mathrm{CI}$

Tapped density measurement ( $n=1$ ) was conducted according to the BP (32). $\mathrm{HR}$ and $\mathrm{Cl}$ were calculated respectively as shown:

$$
\begin{gathered}
\mathrm{HR}=(\mathrm{Vi}) /(\mathrm{Vf}) \\
\mathrm{CI}(\%)=[1-(\mathrm{Vf} / \mathrm{Vi})] \times 100
\end{gathered}
$$

The calculated $\alpha, \mathrm{HR}$, and $\mathrm{Cl}$ were then compared against reference values to provide indications of flowability, using $\alpha$ and HR values, and compressibility using $\mathrm{Cl}$ values.

\section{Blending}

All ingredients except sodium stearylfumaratewere blended in a Turbula ${ }^{\circledR}$ mixer (T2F, WAB AG, Switzerland) at $32 \mathrm{rpm}$ for 10 minutes. Sodium stearylfumaratewas then added followed by mixing for 5 minutes at $80 \mathrm{rpm}$ in a roller mixer(PascallEngineering Ltd., UK). After pre-compression characterisation, blends for the placebo formulation werere-aerated by mixing in the Turbula ${ }^{\circledR}$ mixer at $32 \mathrm{rpm}$ for 5 minutes before tabletting. The blend for the caffeine citrate formulation was not characterised and was tabletted directly.

\section{Tabletting}

Tablets were manufactured by direct compression on a single-punch press (Manesty F3, UK) equipped with round $10 \mathrm{~mm}$ flat-face punches. Target weight was $200 \mathrm{mg}$. Compression force was $25 \mathrm{kN}$.Tabletting speed was 70-80 tablets/minute. Batch size for the placebo tablets was $110 \mathrm{~g}$; and $40 \mathrm{~g}$ for the caffeine citrate tablets. 


\section{Tablet evaluation}

Uniformity of weight was determined as detailed in the BP (33). Acceptable tablet weight was $200 \pm$ $15 \mathrm{mg}$. Thickness and diameter were measured using a micrometer (PK0515, Mitutoyo, Japan).

Friability was measured as described in the BP (34) using a friabilator (Erweka FR1000, Copley, UK). About $6.5 \mathrm{~g}$ of tablets (initial weight, $\mathrm{W}_{\mathrm{o}}$ ) were loaded and the friabilator operated at $25 \mathrm{rpm}$ for 4 minutes. Tablets were de-dusted by shaking over a $1 \mathrm{~mm}$ sieve, and weighed (final weight, $\mathrm{W}_{\mathrm{f}}$ ). Friability was calculated as:

$$
\text { Friability }(\%)=[(\mathrm{Wo}-\mathrm{Wf}) / \mathrm{Wo}] \mathrm{X} 100
$$

Crushing strength was determined ( $n=10$ ) using a hardness tester (Erweka TBH 200, Copley, UK) (35). Tablet tensile strength, $\sigma_{\mathrm{t}}$, was then calculated using the equation proposed by Fell and Newton (36):

$$
\sigma_{\mathrm{t}}(\mathrm{MPa})=2 \mathrm{~F} / \pi \mathrm{DT}
$$

where $F=$ crushing strength $(N), D$ is tablet diameter $(\mathrm{mm})$, and $T$ is tablet thickness $(\mathrm{mm})$.

Porosity was calculated as:

$$
\text { Tablet porosity }(\%)=[(1-\text { tablet solid fraction }) \times 100]
$$

Solid fraction was calculated as apparent tablet density (tablet mass/volume) divided by the true density. True density was measured by helium pycnometer.

Disintegration testing was conducted using a disintegration apparatus (ErwekaZT-34, Copley,UK). The disintegration time was the time taken for 6 tablets to break into particles small enough to pass through the screen of the disintegration chamber. The apparatus was operated at room temperature $\left(19-25^{\circ} \mathrm{C}\right)$. Disintegration medium was distilled water (37). Disintegration time was determined 24 hours after production following storage at controlled conditions ( $50 \% \mathrm{RH} ; 20^{\circ} \mathrm{C}$ ).

Fineness of dispersion was determined using a modification of the BP's test for dispersible tablets (36) where the dispersion produced on disintegration was passed through a $710 \mu \mathrm{m}$ sieve (Pascall, UK). The dispersion passed the test if there were no tablet residues left on the sieve.

The reconstitution behaviour of an optimised placebo formulation in 5 and $10 \mathrm{ml}$ of water at room temperature, simulating likely use conditions, was studied. The time taken for tablets to disintegrate without stirring and the appearance of the final dispersion were noted.

\section{Compaction simulation}

The tableting behaviour of the placebo milk-based tablets was studied by compaction simulation on a rotary tablet press using a Servo-Hydraulic simulator (ESH, UK) equipped with 10-mm flat-faced tooling with tablet target weight set to $200 \mathrm{mg}$. The model formulation used in the compaction studies contained $31.5 \%$ infant formula (SMA ${ }^{\circledR} \mathrm{LF}$ ), $63 \%$ mannitol, $5 \%$ crospovidone, and $0.05 \%$ sodium stearylfumarate. Mannitol was used as a positive control and SMA ${ }^{\circledR}$ LF as a negative control. 


\section{Compatibility determinations}

The solid-state stability of ingredients in the medicated formulation containing caffeine citrate was studied by differential scanning calorimetry (DSC) and Attenuated Total Reflectance

Fourier-Transform Infra-Red (ATR FT-IR). A 1:1 w/w binary mixture of ingredients was prepared by vortexing (HatiRotamixer, UK) for 2 minutes before analyses.

DSC

Samples (3-8mg) were placed in non-hermetically-sealed aluminium pans (Tzero, TA, USA) and heated from $30-300{ }^{\circ} \mathrm{C}$ at a rate of $10^{\circ} \mathrm{C} /$ minute under nitrogen gas purge at a flow rate of 50 $\mathrm{ml} / \mathrm{min}$ (Q2000, TA, USA). Calibration for temperature and heat capacity was carried out using Indium.

FT-IR

Samples were scanned over the range $4000-650 \mathrm{~cm}^{-1}$ with an accumulation of 4 scans per sample at a resolution of $1 \mathrm{~cm}^{-1}$ (Perkin-Elmer, S100, UK).

Where the DSC thermogram or FT-IR spectrogram of the 1:1 w/w mixture was a superimposition of the individual ingredients with no new peaks or absorbance, solid state compatibility was inferred.

\section{Results}

\section{Blend characteristics and tablet properties of the placebo formulations}

The formulations had differing blend characteristics (Table 3). In terms of flow, the "high-milk" blends $\left(\geq 94.5 \%\right.$ milk) had $\alpha$ values $>40$, indicative of poor flow, apart from Marvel ${ }^{\otimes \prime}$ swith values $\leq$ 34 suggesting good flow. Similarly, Marvel ${ }^{\circledR}$ was the most compressible (Carr's Index of 12-14); Aptamil $^{\circledR} 1, \mathrm{Nido}^{\circledR}$, and SMA ${ }^{\circledR}$ LF had higher values of $16-25$.

All tablets had acceptable mean weights (185 to $215 \mathrm{mg}$ ), except for one Nido ${ }^{\circledR}$ formulation (Table $3 b, N 13$ ) which was slightly outside the desired range.

Disintegration time increased as the milk or formula content increased (Figures1a-d).

Marvel ${ }^{\circledR}$ produced formulations had the highest tensile strengths, with friabilities< $1 \%$ (Figure $1 \mathrm{~d}$ ), confirming Marvel ${ }^{\circledR}$ as the most compressible of the products assessed.

Most of the tablets on disintegration produced dispersions that had a few particles about $710 \mu \mathrm{m}$; possibly from swollen milk, or aggregated crospovidone, particles.

\section{Placebo optimum formulations}

The models used for optimisation had acceptable validity or predictive values (Table 4).

The maximum amount of milk that could be incorporated into the tablets was similar for all products, ranging from $24 \%$ for SMA ${ }^{\circledast}$ LF to $28 \%$ with Nido ${ }^{\circledR}$ (Table 5). Predicted and actual disintegration times did not exactly match, but all optimised formulations disintegrated in $<3$ minutes. For $\mathrm{Aptami}^{\circledR} 1$ and $\mathrm{Nido}^{\circledR}$, the formulations presented in the table contained the next higher amount of milk in the simplex matrix used for optimisation. With Aptamil ${ }^{\circledR} 1$, this was because the formulation with the highest amount of milk (27\%) had a friability of $2.7 \%$ : tabletting 
the formulation with the next highest amount of milk gave tablets with an acceptable friability $<1 \%$. For $\mathrm{Nido}^{\circledR}$, the tablet with the highest amount ( $29 \%$ milk) disintegrated in $>3$ minutes ( 198 seconds); thus the formulation with the next higher amount of milk was tabletted.

Tablet tensile strengths differed with Marvel ${ }^{\circledR}$ produced tablets having the highest value (2.45 $\left.\mathrm{MPa}\right)$, and $\mathrm{Nido}^{\circledR}$ produced tablets the least $(0.87 \mathrm{MPa})$.

\section{Compaction simulation}

Compression force and press type affect tablet properties and disintegration time. The influence of compression force on tablet tensile strength, solid fraction, and disintegration time of a model placebo formulation under actual high-speed tableting conditions was studied by compaction simulation. The studies showed that crushing strength peaked at a compression force of about $10 \mathrm{kN}$ for $S M A^{\circledR}$ LF; and did not change much between 10 and $30 \mathrm{kN}$ for the 1:2 mixture of SMA ${ }^{\circledR} \mathrm{LF}$ and mannitol. The maximum tensile strength achieved for each of the formulations differed, illustrating a difference in tabletability between the infant formula and the SMA ${ }^{\circledR}$ LF: mannitol composition.Mannitol alone exhibited tensile strength increasing linearly across the range of compression forces (Figure 2a). Tablet solid fractions also increased with compression force, peaking at about $15 \mathrm{kN}$ for both $S M A^{\circledR} \mathrm{LF}$ and the $S M A^{\circledR} \mathrm{LF}$ : mannitol composition. For instance, with the $\mathrm{SMA}^{\circledR}$ LF: mannitol composition, tablet solid fraction increased from 0.87 at $6.5 \mathrm{kNto}$ a maximum of 0.94 at $13 \mathrm{kN}$, with a consequent decrease in porosity from $13 \%$ to $5 \%$ (Figure $2 \mathrm{~b}$ ). With the $1: 2$ mixture of SMA ${ }^{\circledast} \mathrm{LF}:$ mannitol, disintegration time, and tensile strength, increased with compression force; with disintegration time increasing from about 70 seconds (1.2 minutes) at $6.5 \mathrm{kN}$ to 160 seconds ( 2.7 minutes) at about $25 \mathrm{kN}$ (Figure 2c). These studies thus indicated a positive relationship between compression force, tensile strength, solid fraction, and disintegration time.

\section{Reconstitution behaviour}

A sample of the optimisedplacebo formulation containing $28 \% \mathrm{Nido}^{\circledR}$ disintegrated in about 2 minutes in $5 \mathrm{ml}$ and $10 \mathrm{ml}$ of water at room temperature to produce milky suspensions (Figure 3 ).

\section{Formulation with an API}

Having the milk-based dispersible tablet platform challenged with a BCS I API did not change disintegration time. The inclusion of a caffeine citrate (30\%) did not alter the disintegration time of the platform. When compressed at $20 \mathrm{kNto}$ give tablets with a friability $<1 \%$, disintegration time was $<3$ minutes (Table 6).

\section{Compatibility}

The ingredients in the medicated formulation with Aptamil ${ }^{\circledR} 1$ showed compatibility.DSC results are presented in Figure 4a-d. With Aptami ${ }^{\circledR} 1$, (Figure 4a), protein denaturation from Aptamil ${ }^{\circledR} 1$ at $\approx 150$ ${ }^{\circ} \mathrm{C}$ and the melting point $(\mathrm{mp})$ of caffeine $\left(164.45^{\circ} \mathrm{C}\right)$ are visible. With sodium stearylfumarate(Figure $4 b)$, peak shifts and the absence of its exothermic peak suggest some interactions or incompatibility. With mannitol (Figure $4 \mathrm{c}$ ), the emergence of a new endothermic peak at $153.9^{\circ} \mathrm{C}$; different from the $\mathrm{mp}$ of caffeine citrate $\left(164.45^{\circ} \mathrm{C}\right)$ and mannitol $\left(166.22^{\circ} \mathrm{C}\right)$ suggest the formation of a euthetic mixture. DSC thermograms showed no interactions with crospovidone (Figure $4 \mathrm{~d}$ ), with water loss from crospovidone at $\approx 95^{\circ} \mathrm{C}$ and the mannitolmpat $\approx 165^{\circ} \mathrm{C}$ visible in the composite thermogram. 
FT-IR results are presented in Figure 5a-d. All spectra showed no incompatibility in the solid state. For each binary mixture, the spectrum was a superimposition of the two components, and there were no changes in characteristic FT-IR absorbances.

While the results from the DSC seemed to suggest interactions between caffeine citrate and sodium stearyl fumarate, these were not detected with FT-IR. The clinical significance of the formation of a possible euthetic mixture between caffeine citrate and mannitol is not known.

\section{Discussion}

Excipients were selected based on function such as solubility and known use and lack of safety issues in children. Mannitol was used as filler-binder with sweetening action and the direct-compression grade with an average particle size of $250 \mu \mathrm{m}$ was selected to ensure good flow $(37,38)$. Crospovidone was selected as the superdisintegrant of choice and was used in the recommended range (38). Sodium stearylfumaratewas selected as its relatively hydrophilic nature helps it serve as a lubricant without adversely affecting disintegration time (39). It was used here at the minimum amount of $0.5 \%$ (38). All excipients are precedented in children's medicines (41), and, in the amounts used, are generally recognised as safe (GRAS).

Powder blend flowability and compressibility are essential for tabletting by direct compression. Two simple indicators of how a powder would flow during tablettingare provided by Hausner Ratio and angle-of-repose values. A blend with a Hausner Ratio value $<1.25$, or angle-of-repose $<40^{\circ}$, can be considered to have a flow sufficient as to be tabletted. Blends withangle-of-repose $>50^{\circ}$ are considered not suitable for manufacturing (32). Thus, of all the "high-milk" formulations, only those of Marvel ${ }^{\circledR}$, with angle-of-repose $\leq 34^{\circ}$, had suitable flowability for manufacturing by direct compression. The other "high-milk" formulations were not suitably flowable for direct compression purposes, and may need reformulation to include flow aids.

Compressibility is often predicted using Carr's Index; the lower this is, the greater the ability of the material to undergo volume reduction on the application of a load. In turn, the capacity to form tablets with tensile strengths considered acceptable $-\geq 0.8-1 \mathrm{MPa}-$ is influenced by the composition of the material and compression force (42-45). A material must deform or undergo bond breakage or molecular rearrangement on application of a load and form relatively stable new bonds on load removal in order to form mechanically strong compacts. It is known that hydrophobic/oily substances oppose particle-particle bonding and can lead to low-strength compacts (46). This is thought to be the reason why the "high-milk" and 1:1 combinations of the high milk-fat containing powder blends of $\mathrm{Nido}^{\circledast}{ }$, Aptamil $^{\circledR} 1$, and SMA ${ }^{\circledR}$ LF produced tablets with tensile strengths $<1 \mathrm{MPa}$ while the low milk-fat containing Marvel ${ }^{\circledR}$ produced tablets with tensile strengths $>1 \mathrm{MPa}$. Thus, overall, Marvel ${ }^{\circledR}$ was the most processable and tablettable milk powder. The other high milk-fat containing powder blends might benefit from the inclusion of a binder.

All optimised placebo formulations contained approximately the same amount of milk, regardless of the type. However, at a mean of $25 \%$, one $200 \mathrm{mg}$ tablet dispersed in $5-10 \mathrm{ml}$ of water would produce a suspension 12-16 times less concentration than reconstituted powdered milk. 
One quality requirement for compressed tablets is a friability $<1 \%$. This ensures that the tablets are sufficiently robust to withstand further processing and handling during transportation and storage (34). This limit was adopted for the optimum placebo formulation and caffeine citrate tablets.

The influence of compression force on tablet properties of a reference formulation with $31.5 \% \mathrm{SMA}^{\circledR}$ LF was studied using compaction simulation. This amount of milk was based on experimental data which showed that a formulation with $31.5 \%$ Aptamil $^{\circledR} 1,63 \%$ mannitol, $5 \%$ crospovidone, and $0.5 \%$ SSF had the lowest disintegration times of all the milk-containing formulations. It was decided to substitute Aptamil $^{\circledR} 1$ with the more poorly-compressible SMA ${ }^{\circledast}$ LF to obtain information that may be applicable to the other milk and formula powders. The results suggested a positive relationship between compression force, tensile strength, and disintegration time, in agreement with other studies with tablets produced by direct compression (47-49).

Preformulation studies with caffeine citrate indicated no solid-state instability. The inclusion of this hydrophilic API (50) in the milk-based formulation still produced dispersible tablets. This was despite the fact that the spray-dried grade of mannitol with better compressibility which gave rise to tablets with a higher tensile strength was used (51). It is thought that the inclusion of the same amount of a hydrophobic API, on the other hand, if it leads to the tablet being less wettable, may prolong disintegration time. More studies are warranted.

While this work used direct compression as a low-cost production technique for the dispersible tablet, advances in tablet manufacturing mean that other relatively low-cost production techniques such as 3D printing may also be applicable for the rapid production of individualised doses of medicines using this platform in the future $(52,53)$.

This work did not aim at a complete organoleptic evaluation of the milk-based platform. However, It is possible to include intense sweeteners such as neotame and flavours such as vanilla to improve the organoleptic properties of these milk-based tablets, and hence paediatric acceptability.

\section{Conclusions}

A milk-based dispersible tablet formulation that redisperses in water to form a suspension with similar organoleptic properties with milk might be a useful drug delivery platform to improve adherence in young children. This work demonstrated that the low-cost production of such a platform by direct compression is technically feasible. This platform can be used in the formulation of low-dose APIs, OTC products, or multivitamin preparations.

\section{Acknowledgement}

Roquette, UK, ISP, UK, and SPI Pharma, USA are acknowledged for the gift samples.

Pfizer Ltd, UK for the use of the compaction simulator. Dr Anne Cram and Dr Kate Kinslow for support with the compaction simulation and with the manuscript. This work would not be possible without the help of two MPharm students, Shirley Vijayakumar and Katarina Vaskova-Whittingham, and their contribution is hereby acknowledged. 


\section{References}

1. Ivanovska, V, Rademaker CMA, van Dijk L, Mantel-Teeuwisse, AK. Paediatric drug formulations: A review of challenges and progress. Paed. 2014; 134: 361. doi: 10.1542/peds.2013-3225.

2. Kozarewicz P. Regulatory perspectives on acceptability testing of dosage forms in children. IntJPharm. 2014; 469: 245-248.doi:10.1016/j.ijpharm.2014.03.057.

3. Nunn T, Williams J. Formulation of medicines for children. Br J Clin Pharmacol.2005; 59(6): 674-676.doi: 10.1111/j.1365-2125.2005.02410.x.

4. Davies EH, Tuleu C. Medicines for children: a matter of taste. J Pediatr. 2008; 153(5): 604. doi: 10.1016/j.jpeds.2008.06.030.

5. WHO. Development of paediatric medicines: points to consider in pharmaceutical development (2011). http://www.who.int/medicines/areas/quality_safety/quality_assurance/Rev3PaediatricMedicinesDevelopment_QAS08-257Rev3_17082011.pdf. Accessed 14 Dec 2011.

6. McDaniel MR, Barker E, Lederer CL. Sensory characterization of human milk. J Dairy Sci.1989; 72 (5): 1149-1158

7. Alves JGB, Russo PC, Alves GV. Facial responses to basic tastes in breastfeeding and formula-feeding infants. BreastfeedMed. 2013; 8(2): 235-236. doi:10.1089/bfm.2012.0092.

8. Schwartz C, Charbanet C, Laval C, Issanchou S, Nicklaus S. Breast-feeding duration: influence on taste acceptance over the first year of life. Bri J Nutr. 2013; 109(6): 1154-1161. doi: $10.1017 /$ S0007114512002668.

9. Sousa SG, Delgadillo I, Saraiva JA. Human milk composition and preservation: Evaluation of high-pressure processing as a non-thermal pasteurisation technology. Crit Rev Food SciNutr. doi: $10.1080 / 10408398.2012 .753402$.

10. Watson Dairy Consulting. Milk powder production. 2015. www.dairyconsultant.co.uk/pdf/milk_powder_production.pdf . Accessed 16 Mar 2015.

11. FAO and WHO. Milk and milk products. $2^{\text {nd }}$ Edition. 2011. http://www.fao.org/docrep/015/i2085e/i2085e00.pdf. Accessed 29 Oct 2012.

12. WHO. Complementary feeding. 2015. http://www.who.int/nutrition/topics/complementary_feeding/en/ Accessed 30 Apr 2015.

13. The Caroline Walker Trust. Infant milk in the UK. 2011. http://www.cwt.org.uk/pdfs/infantsmilk_web.pdf. Accessed 29 Oct 2012.

14. Charkoftaki G, Kytariolos J, Macheras P. Novel milk-based oral formulations: proof of concept. Int J Pharm. 2010; 390 (2): 150-159.doi:10.1016/j.ijpharm.2010.01.038.

15. Macheras $P$, inventor; Pharmathen S.A, assignee. Pharmaceutical formulation containing lipophilic drugs and milk as a solubilizing/dispensing agent and method for the preparation thereof. United States patent application publication. US20130190252 A1. 2013 Jul 25.

16. Şahin, N.O., Arslan, H. Inclusion complex of prednisolone with skimmed milk: Part I: physicochemical characterization. YakugakuZasshi, 2007; 127(8): 1255-1261. 
17. Bennett, S.M, Zhou, L., Hayes, J.E. Using milk fat to reduce the bitterness and irritation of Ibuprofen. ChemosensPercept. 2012; 5: 231-236.doi 10.1007/s12078-012-9128-6.

18. Shroppolo F, Ciccarello F, Milani R, Bellorini L, inventors. Pharmaceutical composition comprising skim milk powder. United States patent US 20050118258. 2005 Jun 2.

19. Shibata M, Toyoda I, Kudo S, inventors; Meiji Dairies Corporation, assignee. Solid milk and method for manufacturing thereof. United States patent US20080292770 A1. 2008 Nov 27.

20. Shibata M, Otsubo K, Nakane S, Niwa T, Danjo K. Tabletting of powdered milk and the resulting physical properties. YakugaZasshi. 2011; 131(10): 1503-1507. Japanese.

21. Ndife LI, Booker III LT, Hohman SL, inventors; Abbott Laboratory, assignee. Infant formula. United States patent US7070825 B2. 2006 Jul 4.

22. Pinto, J.T, Brachkova, M., Fernades, A.I., Pinto, J.F. 2015. Evaluation of the ability of powdered milk to produce mini-tablets delivery of paracetamol in paediatrics. Oral presentation. 7th International Granulation Workshop, University of Sheffield, UK. [Online]. Available from:

http://www.shef.ac.uk/polopoly_fs/1.472578!/file/2015_abstract_list_granulation_worksho p.pdf [Accessed 18 August 2015].

23. E Teunou, J.J Fitzpatrick, E.C Synnott, Characterisation of food powder flowability, Journal of Food Engineering, Volume 39, Issue 1, January 1999, Pages 31-37, ISSN 0260-8774, http://dx.doi.org/10.1016/S0260-8774(98)00140-X.

24. Liu LX1, Marziano I, Bentham AC, Litster JD, White ET, Howes T. Effect of particle properties on the flowability of ibuprofen powders. Int J Pharm. 2008 Oct 1;362(1-2):109-17. doi: 10.1016/j.ijpharm.2008.06.023.

25. Eriksson L, Johansson E, Kettaneh-Wold N, Wikstrom C, Wold S. Design of experiments: principles and applications. 3rd ed. Umea: Umetrics Academy; 2008. pp. 1-6.

26. DataPharm. Caffeine citrate $10 \mathrm{mg} / \mathrm{ml}$ Oral Solution. Summary of Product Characteristics. https://www.medicines.org.uk/emc/medicine/28345. Assessed 25 Apr 2015.

27. Waitrose. Marvel Original dried skimmed milk powder. 2015. http://www.waitrose.com/shop/ProductView-10317-10001-27217Marvel+Original+dried+skimmed+milk+powder. Accessed 25 Apr 2015

28. Tesco. Nestle Nido Instant Full Cream Milk Powder. 2015. http://www.tesco.com/groceries/Product/Details/?id=260148289. Accessed 25 Apr 2015

29. Boots. SMA Lactose Free from birth. 2015. http://www.boots.com/en/SMA-Lactose-Freefrom-Birth-430g_6986/. Accessed 25 Apr 2015

30. Eriksson L, Johansson E, Kettaneh-Wold N, Wikstrom C, Wold S. Design of experiments: principles and applications. 3rd ed. Umea: Umetrics Academy; 2008. p 41, 231-238.

31. Eriksson L, Johansson E, Kettaneh-Wold N, Wikstrom C, Wold S. Design of experiments: principles and applications. 3rd ed. Umea: Umetrics Academy; 2008. p. 77-78,88

32. British Pharmacopoeia 2015 Volume V. London: The Stationery Office; 2014. Powder flow. p. 518-519. 
33. British Pharmacopoeia 2015 Volume V. London: The Stationery Office; 2014. Consistency of Formulated Preparations. p. 371.

34. British Pharmacopoeia 2015. Volume V. London: The Stationery Office; 2014. Friability. p. 511.

35. British Pharmacopoeia 2015. Volume V. London: Stationery Office; 2014. Resistance to Crushing of Tablets. p. 513.

36. Fell, JT, Newton, JM. The tensile strength of tablets. J Pharm Pharmacol. 1968; 657-658.

37. British Pharmacopoeia 2015 Volume III. London: The Stationery Office; 2014. Dispersible tablets. p. 75.

38. Rowe RC, Sheskey PJ, Quinn ME. Handbook of Pharmaceutical Excipients, 6th ed. Pharmaceutical Press and American Pharmacists Association. 2012.

39. Roquette. Direct compression solutions. Pearlitol SC and DC for high stability and versatility. http://www.directcompression.roquettepharma.com/ (2015). Accessed 25 Apr 2015.

40. Li J, Wu Y. Lubricants in pharmaceutical solid dosage forms. Lubricants, 2014; 2: 21-43. doi:10.3390/lubricants2010021.

41. Stoltenberg I, Breitkreutz J. Orally disintegrating mini-tablets (ODMTs) - a novel solid oral dosage form for paediatric use. Euro J Pharm Biopharm. 2011; 78: 462469.doi:10.1016/j.ejpb.2011.02.005

42. Kushner J, Langdon BA, Hicks I, Song D, Li F, Kathiria L, Kane A, Ranade G, Agarwal K. A quality-by-design study for an immediate-release tablet platform: examining the relative impact of active pharmaceutical agent properties, processing methods, and excipient variability on drug product quality attributes. J Pharm Sci. 2014; 103(2): 527-38.doi: $10.1002 /$ jps. 23810

43. Pitt KG, Heasley MG. Determination of the tensile strength of elongated tablets. Powder Technol. 2013; 238: 169-175.doi:10.1016/j.powtec.2011.12.060.

44. McCormick D. Evolutions in direct compression. Pharm Technol. 2005. http://images.alfresco.advanstar.com/alfresco_images/pharma/2014/08/22/ef1aff6d-1dbf44f1-86c2-2bfafaf053ff/article-155374.pdf Accessed 25 Apr 2013.

45. Zhang JY, Ternik N. Development of low-dose solid oral tablets using direct compression. In: Zhang, JY, editor. Formulation and analytical development for low dose oral drug products. New Jersey: John Wiley \& Sons Inc.; 2009. p. 188.

46. Bhandari B, Bansal N, Zhang M, Schuck P. Handbook of food powders: processes and properties. 1st ed. Cambridge: Woodhead; 2013. p. 457.

47. Kitazawa S, John OI, Ito Y, Teramura S, Okado J. Effect of hardness on the disintegration time and the dissolution rate of uncoated caffeine tablets. J Pharm Pharmacol. 1975; 27(10): 765-770.

48. Schiermeier S, Schmidt PC. Fast dispersible ibuprofen tablets. Eur J Pharma Sci. 2002; 15(3):295-305. 
49. Pabani RM, Rantoola Z. Application of face-centred central design to optimize compression force and tablet diameter for the formulation of mechanically strong and fast disintegrating orodispersible tablets. Int J Pharm. 2012; 430(1-2): 18-25.doi:

10.1016/j.ijpharm.2012.03.021.

50. Wu CY, Benet LZ. Predicting drug disposition via application of BCS:

transport/absorption/elimination interplay and development of a biopharmaceutics drug disposition classification system. Pharm Res. 2005; 22: 11-23.

51. Al-khattawi A, Mohammed AR. Compressed orally disintegrating tablets: excipients evolution and formulation strategies. Expert Opin Drug Deliv. 2013; 10(5): 651-663.doi: 10.1517/17425247.2013.769955.

52. Goyanes A, Buanz AB, Basit AW, Gaisford S. Fused-filament 3D printing (3DP) for fabrication of tablets. Int J Pharm. 2014; 476(1-2):88-92. doi: 10.1016/j.ijpharm.2014.09.044.

53. Goyanes A, Wang J, Buanz A, Martínez-Pacheco R, Telford R, Gaisford S, Basit AW. 3D printing of medicines: engineering novel oral devices with unique design and drug release characteristics.Mol Pharm. 2015; 2:12(11):4077-84. doi:

10.1021/acs.molpharmaceut.5b00510. 


\begin{tabular}{lcccc}
\hline $\begin{array}{l}\text { Nutrient (typical values } \mathbf{g} / \mathbf{1 0 0} \mathbf{g} \\
\text { powder) }\end{array}$ & MARVEL $^{\circledR}$ & NIDO $^{\circledR}$ & APTAMIL $^{\circledR} \mathbf{1}$ & SMA $^{\circledR}$ LF \\
\hline Protein & 36.1 & 25.7 & 10 & 12 \\
Carbohydrate & 52.9 & 36.5 & 55 & 55 \\
of which lactose & 52.9 & 36.5 & 52 & $<0.052$ \\
Fat & 0.6 & 28.2 & 25 & 28 \\
\hline
\end{tabular}

Table 2 Factors and levels in the design-of-experiment

\begin{tabular}{lcc}
\hline Factor (\% tage composition) & Low level (\%) & High level (\%) \\
\hline Milk/Infant formula & 0.0 & 97.5 \\
Mannitol & 0.0 & 97.5 \\
Crospovidone & 2.0 & 5.0 \\
Sodium stearylfumarate & 0.5 & 0.5 \\
\hline
\end{tabular}


Table 3 Experimental worksheet with randomisation (run) order, composition, blend characteristics, and tablet weight for: (a) skimmed-milk powder, Marvel ${ }^{\circledR}$, (b) full-fat milk powder, $\mathrm{Nido}^{\circledR}$, (c) full-fat infant formula, Aptamil ${ }^{\circledR} 1$, and (d) specialist lactose-free infant formula, $S M A^{\circledR} L F$

\begin{tabular}{|c|c|c|c|c|c|c|c|c|c|}
\hline \multirow[b]{2}{*}{ Exp. } & \multirow{2}{*}{$\begin{array}{l}\text { Run } \\
\text { order }\end{array}$} & \multicolumn{4}{|c|}{ Formulation composition, $\%$} & \multicolumn{3}{|c|}{$\begin{array}{c}\text { Blend } \\
\text { characteristics }\end{array}$} & \multirow{2}{*}{$\begin{array}{c}\text { Tablet } \\
\begin{array}{c}\text { Weight } \\
\text { (mg) }\end{array}\end{array}$} \\
\hline & & Marvel $^{\circledR}$ & Mannitol & Crosp & SSF & C.I & H.R & $\alpha$ & \\
\hline N1 & 4 & 0 & 97.5 & 2 & 0.5 & 12 & 1.1 & 24 & 208.6 \\
\hline N2 & 5 & 97.5 & 0 & 2 & 0.5 & 12 & 1.1 & 29 & 205.4 \\
\hline N3 & 10 & 0 & 94.5 & 5 & 0.5 & 12 & 1.1 & 23 & 200.6 \\
\hline N4* & 6 & 94.5 & 0 & 5 & 0.5 & 14 & 1.2 & 30 & 202.5 \\
\hline
\end{tabular}




\begin{tabular}{|c|c|c|c|c|c|c|c|c|c|}
\hline N5 & 13 & 96.5 & 0 & 3 & 0.5 & 12 & 1.1 & 32 & 196.6 \\
\hline N6 & 9 & 95.5 & 0 & 4 & 0.5 & 13 & 1.2 & 34 & 207.2 \\
\hline N7 & 12 & 0 & 96.5 & 3 & 0.5 & 10 & 1.1 & 24 & 203.4 \\
\hline N8 & 11 & 0 & 95.5 & 4 & 0.5 & 13 & 1.2 & 23 & 203.1 \\
\hline N9 & 14 & 65 & 32.5 & 2 & 0.5 & 14 & 1.2 & 30 & 206 \\
\hline N10 & 8 & 31.5 & 63 & 5 & 0.5 & 13 & 1.1 & 29 & 204.4 \\
\hline N11* & 3 & 48 & 48 & 3.5 & 0.5 & 18 & 1.2 & 27 & 205.8 \\
\hline N12 & 1 & 48 & 48 & 3.5 & 0.5 & 14 & 1.2 & 26 & 204.5 \\
\hline N13 & 2 & 48 & 48 & 3.5 & 0.5 & 14 & 1.2 & 21 & 206 \\
\hline N14 & 7 & 48 & 48 & 3.5 & 0.5 & 11 & 1.1 & 28 & 204.5 \\
\hline & \multicolumn{5}{|c|}{ Formulation composition, \% } & \multicolumn{3}{|c|}{$\begin{array}{c}\text { Blend } \\
\text { characteristics }\end{array}$} & Tablet \\
\hline Exp. & order & $\mathrm{Nido}^{\oplus}$ & Mannitol & Crosp & SSF & C.I & H.R & $\alpha$ & $\begin{array}{c}\text { Weight } \\
\text { (mg) }\end{array}$ \\
\hline N1 & 1 & 97.5 & 0 & 2 & 0.5 & 25 & 1.3 & 50 & 205.3 \\
\hline N2 & 6 & 0 & 97.5 & 2 & 0.5 & 17 & 1.2 & 23 & 208.4 \\
\hline N3 & 11 & 94.5 & 0 & 5 & 0.5 & 16 & 1.2 & 54 & 206.2 \\
\hline N4* & 3 & 0 & 94.5 & 5 & 0.5 & 13 & 1.2 & 22 & 211.5 \\
\hline N5 & 9 & 0 & 96.5 & 3 & 0.5 & 12 & 1.1 & 22 & 207.6 \\
\hline N6 & 12 & 0 & 95.5 & 4 & 0.5 & 8 & 1.1 & 23 & 205.4 \\
\hline N7 & 8 & 96.5 & 0 & 3 & 0.5 & 19 & 1.2 & 55 & 210.2 \\
\hline N8 & 14 & 95.5 & 0 & 4 & 0.5 & 16 & 1.2 & 54 & 202.9 \\
\hline N9 & 13 & 32.5 & 65 & 2 & 0.5 & 15 & 1.2 & 31 & 201.2 \\
\hline N10 & 4 & 63 & 31.5 & 5 & 0.5 & 16 & 1.2 & 63 & 204.3 \\
\hline N11 & 5 & 48 & 48 & 3.5 & 0.5 & 13 & 1.2 & 35 & 204.1 \\
\hline $\mathrm{N} 12$ & 2 & 48 & 48 & 3.5 & 0.5 & 14 & 1.2 & 33 & 210.3 \\
\hline N13*1 & 10 & 48 & 48 & 3.5 & 0.5 & 15 & 1.2 & 35 & 217.5 \\
\hline N14 & 7 & 48 & 48 & 3.5 & 0.5 & 12 & 1.1 & 39 & 207.5 \\
\hline
\end{tabular}

\begin{tabular}{|c|c|c|c|c|c|c|c|c|c|}
\hline \multirow[b]{2}{*}{ Exp. } & \multirow{2}{*}{$\begin{array}{l}\text { Run } \\
\text { order }\end{array}$} & \multicolumn{4}{|c|}{ Formulation composition, \% } & \multicolumn{3}{|c|}{$\begin{array}{c}\text { Blend } \\
\text { characteristics }\end{array}$} & \multirow{2}{*}{$\begin{array}{c}\text { Tablet } \\
\begin{array}{c}\text { Weight } \\
(\mathrm{mg})\end{array}\end{array}$} \\
\hline & & Aptamil $^{\circledR} 1$ & Mannitol & Crosp & SSF & C.I & $H . R$ & $\alpha$ & \\
\hline N1 & 11 & 0 & 97.5 & 2 & 0.5 & 10 & 1.1 & 17 & 204.1 \\
\hline N2 & 8 & 97.5 & 0 & 2 & 0.5 & 17 & 1.2 & 49 & 199.3 \\
\hline N3 & 10 & 0 & 94.5 & 5 & 0.5 & 10 & 1.1 & 17 & 200.8 \\
\hline N4* & 2 & 94.5 & 0 & 5 & 0.5 & 17 & 1.2 & 44 & 202.6 \\
\hline N5 & 5 & 96.5 & 0 & 3 & 0.5 & 17 & 1.2 & 49 & 205.5 \\
\hline
\end{tabular}




\begin{tabular}{cccccccccc} 
N6 & 14 & 95.5 & 0 & 4 & 0.5 & 16 & 1.2 & 52 & 201.5 \\
N7 & 13 & 0 & 96.5 & 3 & 0.5 & 10 & 1.1 & 18 & 204.2 \\
N8 & 12 & 0 & 95.5 & 4 & 0.5 & 11 & 1.1 & 17 & 203.4 \\
N9 & 9 & 65 & 32.5 & 2 & 0.5 & 10 & 1.1 & 17 & 208.9 \\
N10 & 6 & 31.5 & 63 & 5 & 0.5 & 15 & 1.2 & 28 & 208.3 \\
N11 & 1 & 48 & 48 & 3.5 & 0.5 & 18 & 1.2 & 25 & 206.6 \\
N12 & 7 & 48 & 48 & 3.5 & 0.5 & 14 & 1.2 & 30 & 209 \\
N13* & 4 & 48 & 48 & 3.5 & 0.5 & 17 & 1.2 & 30 & 207.7 \\
N14 & 3 & 48 & 48 & 3.5 & 0.5 & 15 & 1.2 & 25 & 209.3 \\
\hline & & & & & & & & & \\
\hline (d) & & & Formulation composition, \% & & & characteristics & Tablet \\
\hline & Run & & & & & & & \\
Exp. & order & SMA LF & Mannitol & Crosp & SSF & C.I & H.R & $\alpha$ & Weight \\
N1 & 4 & 97.5 & 0 & 2 & 0.5 & 24 & 1.3 & 60 & 206.8 \\
N2 & 5 & 0 & 97.5 & 2 & 0.5 & 7 & 1.1 & 22 & 207.7 \\
N3* & 9 & 94.5 & 0 & 5 & 0.5 & 18 & 1.2 & 56 & 209.2 \\
N4 & 14 & 0 & 94.5 & 5 & 0.5 & 11 & 1.1 & 22 & 205.5 \\
N5 & 13 & 0 & 96.5 & 3 & 0.5 & 9 & 1.1 & 20 & 207.2 \\
N6 & 2 & 0 & 95.5 & 4 & 0.5 & 8 & 1.1 & 20 & 203.1 \\
N7* & 8 & 96.5 & 0 & 3 & 0.5 & 21 & 1.3 & 58 & 213.9 \\
N8 & 10 & 95.5 & 0 & 4 & 0.5 & 24 & 1.3 & 59 & 205.9 \\
N9 & 1 & 32.5 & 65 & 2 & 0.5 & 14 & 1.2 & 30 & 203.5 \\
N10 & 11 & 63 & 31.5 & 5 & 0.5 & 27 & 1.4 & 48 & 200.8 \\
N11 & 12 & 48 & 48 & 3.5 & 0.5 & 19 & 1.2 & 43 & 203.5 \\
N12 & 3 & 48 & 48 & 3.5 & 0.5 & 13 & 1.2 & 32 & 197.9 \\
N13* & 7 & 48 & 48 & 3.5 & 0.5 & 18 & 1.2 & 40 & 206.1 \\
N14 & 6 & 48 & 48 & 3.5 & 0.5 & 13 & 1.2 & 43 & 203.3 \\
\hline & & & & & & & & & \\
\hline
\end{tabular}

Notes:

* Experiments excluded from the regression analysis. Crosp = crospovidone, SSF = sodium stearylfumarate; C.I = Carr's Index; H.R = Hausner Ratio; $\alpha=a n g l e$ of repose. 1 . The variation in tablet weight could be attributable to operational error in manually adjusting the powder compression volume in the tablet press. However, as this result was excluded in the analysis, there is no influence in the interpretation of the results.

Table 4 Diagnostic values of validity and predictability for adjusted regression models used for formulation optimisation.

\begin{tabular}{cccccc}
\hline & $\mathbf{R}^{\mathbf{2}}$ & $\mathbf{Q}^{\mathbf{2}}$ & $\mathbf{R}^{\mathbf{2}}-\mathbf{Q}^{\mathbf{2}}$ & $\begin{array}{c}\text { Model } \\
\text { validity }\end{array}$ & $\begin{array}{c}\text { Residual } \\
\text { standard } \\
\text { deviation } \\
\text { (RSD) }\end{array}$ \\
\hline Aptamil $^{\circledR} \mathbf{1}$ & 0.975 & 0.92 & 0.055 & 0.95 & 66.84 \\
Marvel $^{\circledR}$ & 0.992 & 0.98 & 0.012 & 0.40 & 97.98 \\
Nido $^{\circledR}$ & 0.989 & 0.96 & 0.029 & 0.27 & 73.15 \\
SMA $^{\circledR}$ LF & 0.77 & 0.67 & 0.1 & $<0.25$ & 215.2 \\
\hline
\end{tabular}


Notes: (I). Acceptable (target) values are: $R^{2}$ (Goodness-of-fit) and $\mathrm{Q}^{2}$ (Goodness of prediction) $>0.5 ; \mathrm{R}^{2}-\mathrm{Q}^{2}<$ 0.3 ; model validity $>0.25$. (II) While SMA ${ }^{\oplus}$ LF had model validity less than the target; $Q^{2}$ was good enough for the model to be accepted. 
Table 5 Composition of the optimum formulations and properties of corresponding tablets compressed at $25 \mathrm{kN}$.

\begin{tabular}{|c|c|c|c|c|c|c|c|c|c|c|c|c|c|c|}
\hline \multicolumn{5}{|c|}{ Formulation composition (\%) } & \multicolumn{3}{|c|}{ Blend properties } & \multicolumn{7}{|c|}{ Tablet properties } \\
\hline \multirow{2}{*}{\multicolumn{2}{|c|}{ Milk/ Infant formula }} & \multirow[t]{2}{*}{ Man } & \multirow[t]{2}{*}{ Cro } & \multirow[t]{2}{*}{ SSF } & \multirow[t]{2}{*}{$\alpha$} & \multirow[t]{2}{*}{$\mathrm{HR}$} & \multirow[t]{2}{*}{$\mathrm{Cl}$} & \multirow[t]{2}{*}{$\begin{array}{l}\text { Weight (mg) } \\
\text { (mean } \pm \mathrm{s} . \mathrm{d})\end{array}$} & \multirow[t]{2}{*}{$\begin{array}{c}\text { Thickness } \\
(\mathrm{mm})\end{array}$} & \multirow[t]{2}{*}{$\begin{array}{c}\text { Diameter } \\
(\mathrm{mm})\end{array}$} & \multirow{2}{*}{$\begin{array}{c}\text { Tensile } \\
\text { strength } \\
(\mathrm{MPa})\end{array}$} & \multirow[t]{2}{*}{$\begin{array}{c}\text { Friability } \\
(\%)\end{array}$} & \multicolumn{2}{|c|}{$\begin{array}{l}\text { Disintegration time } \\
\text { (sec) }\end{array}$} \\
\hline & & & & & & & & & & & & & Predicted & Actua \\
\hline Aptamil $^{\circledR} 1$ & 22.58 & 73.12 & 3.8 & 0.5 & 30 & 1.18 & 15 & $198.6 \pm 1$ & 1.81 & 10.08 & 1.17 & 0.8 & 153 & 128 \\
\hline Marvel ${ }^{\circledR}$ & 26.98 & 67.87 & 4.65 & 0.5 & 28 & 1.16 & 14 & $200.3 \pm 3$ & 1.81 & 10.05 & 2.45 & 0.7 & 153 & 127 \\
\hline Nido $^{\circledR}$ & 27.73 & 68.25 & 4.67 & 0.5 & 31 & 1.17 & 15 & $201.1 \pm 1$ & 1.88 & 10.08 & 0.87 & 0.7 & 128 & 157 \\
\hline SMA $^{\circledR}$ LF & 23.45 & 71.1 & 4.93 & 0.5 & 29 & 1.21 & 17 & $200.2 \pm 3$ & 1.86 & 10.08 & 1.15 & 0.6 & 170 & 123 \\
\hline
\end{tabular}

Notes: Man = mannitol; Cro = crospovidone; SSF = sodium stearylfumarate; $\alpha=$ angle of repose; $\mathrm{HR}=\mathrm{Hausner}$ Ratio; $\mathrm{Cl}=\mathrm{Carr}$ 's Index 
Table 6 Tablet properties of a milk-based formulation containing caffeine citrate as a model API

\begin{tabular}{lcc}
\hline Formulation composition & (\%) & $\begin{array}{c}\text { Amount } \\
\text { weighed (g) }\end{array}$ \\
\hline Aptamil ${ }^{\circledR}$ 1 & 23 & 9.2 \\
Caffeine citrate $^{(}$200 SD) & 30 & 12 \\
Mannitol(Pearlitol & 41.77 & 16.71 \\
Crospovidone & 4.73 & 1.89 \\
Sodium stearylfumarate & 0.5 & 0.2 \\
& 100 & 40 \\
Tablet properties & & \\
Weight uniformity (mg) & & $201 \pm 1^{*}$ \\
Tensile strength (MPa) & & $1.93 \pm 0.15^{*}$ \\
Friability (\%) & & 0.8 \\
Disintegration time (sec) & & 167 \\
\hline
\end{tabular}

* Values are mean \pm s.d; $n=10$ 